\title{
PEMANFAATAN MIKRO DAN MARKETING GUNA MENINGKATKAN PEREKONOMIAN DESA DI MASA PANDEMI
}

\author{
Kartika Rose Rachmadi*, Miftakhul Jannah, Celline Ayunda Salsabilla \\ Fakultas Ekonomi dan Bisnis, Universitas Islam Malang \\ *korespondensi email: tikarose@unisma.ac.id
}

\begin{abstract}
ABSTRAK
Pandemi Covid-19 sudah menjadi ancaman baru di Indonesia. Hampir semua kota besar di Indonesia telah terjangkit oleh virus ini. Virus ini membawa dampak yang sangat besar terhadap berbagai sector terutama di Desa Torongrejo Apalagi disaat pandemi seperti ini, orang orang berdiam diri di rumah kecuali pergi untuk kepentingan saja, maka internet sangat membantu untuk bertukar informasi.Hal ini juga dilandasi karena penggunaan internet yang semakin meningkat dari tahun ke tahun. Indonesia sendiri menempati posisi 5 besar pada tahun 2019 sebagai negara dengan pengguna internet terbesar didunia dengan peringkat kelima. Social Media Marketing merupakan salah satu jenis digital marketing untuk memasarkan dan membesarkan brand. Jenis ini sangat banyak digunakan karena lebih mudah dalam memasarkannya maupun menyebarluaskan konten, dimana semua orang banyak menggunakan media sosial dalam kehidupan sehari hari. Dari itu kita bisa memanfaatkan teknologi yang ada untuk membangkitkan ekonomi khususnya dalam pembangunan ekonmi untuk para petani sayur untuk memasarkan produknya melalui internet. Tujuan pengabdian kepada masyarakat ini untuk meningkatkan pembangunan ekonomi saat pandemi dengan memanfaatkan teknologi yang ada di Desa Torongrejo, Kecamatan Junrejo Kota Batu. Metode yang digunakan dalam upaya pengembangan usaha berbasis teknologi adalah metode pendidikan masyarakat dan pelatihan. Materi-materi dalam upaya pengembangan usaha berbasis teknologi pada UMKM Desa Torongrejo melalui pelatihan digital marketing meliputi: 1) Menumbuhan jiwa kewirausahaan dan memberikan insipirasi dari keberhasilan bisnis online, 2) Sharing session, 3) Pelatihan digital marketing. Hasil identifikasi menunjukkan bahwa banyak masyarakat di Desa Torongrejo menggunakan teknologi sederhana dalam pemasaran, yaitu didominasi dengan media Whatsapp dan Facebook. Bahkan masih banyak masyarakat dan UMKM yang menjalankan usahanya secara offline tanpa bantuan teknologi. Hasil evaluasi dari kegiatan pelatihan digital marketing menunjukkan bahwa kegiatan ini mendapatkan tanggapan yang positif, dinilai dapat memberikan wawasan dan ilmu, dan memberikan inspirasi. Hampir seluruh pelaku usaha ingin mempraktekan bisnis online ini dalam pengembangan usahanya.
\end{abstract}

Kata Kunci: desa torongrejo; pemanfaatan digital; perekonomian desa

\section{PENDAHULUAN}

Digitalisasi dapat diartikan sebagai sebuah proses menyimpan seluruh sifat dan informasi dari teks, suara, gambar, atau multimedia dalam sebuah string elektronik dari nol dan satu bit (Wuryantai, 2004). Teknologi Komunikasi dan Informasi ini berkembang sangat pesat, hal ini ditandai dengan banyaknya alat yang berbasis pada informasi maupun komunikasi yang ada di masyarakat. Teknologi Informasi dan Komunikasi sendiri lebih 
merujuk pada teknologi informasi yang kemudian ditambahkan dengan teknologi komunikasi serta area broadcasting yang meliputi internet dan peralatan elektronik lainnya (Fidiana et al., 2021; Islamic Development Bank (IDB), 2003).

Kehadiran internet yang telah mencapai hampir keseluruhan wilayah Indonesia, telah berdampak pada kehidupan masyarakat. Melalui internet masyarakat dapat bertukar informasi tanpa harus bertatap muka (Imaniawan \& Wati, 2017). Penggunaan sistem informasi untuk membantu kinerja pemerintah desa menjadi lebih baik, lebih efisien dan lebih mudah. Dengan didukung oleh kemajuan teknologi informasi yang memungkinkan pengembangan sistem informasi semakin handal (Pardani \& Damayanthi, 2017; Paryanta et al., 2017).

Perkembangan dunia e-commerce saat ini semakin meningkat, beberapa kemudahan yang disuguhkannya membuat banyak orang menjadi tertarik (Sugara \& Dewantara, 2017). E-commerce atau electronic commerce merupakan sebuah mekanisme dalam pengelolaan bisnis secara elektronik, fokusnya adalah pada transaksi bisnis jual beli individu melalui media internet.

Teknologi elektronik berbasis internet ini mempertemukan penjual dan pembeli secara langsung dan melakukan pertukaran barang tanpa harus bertatap muka seperti yang ada di pasar tradisional. Hadirnyae-commerce ini mempersingkat waktu untuk saling berhubungan, antara perusahaan dengan entitas bisnis lainnya Ini karena dengan ecommerce prosesnya lebih cepat, intensif dan murah dibandingkan pada manajemen pasar. Penjualan barang melalui online sudah mulai mengalahkan toko yang ada di pasar. Hal ini dikarenakan oleh beberapa faktor yaitu kemudahan (Alwafi \& Magnadi, 2016; Rizal et al., 2019), kepercayaan dan kepuasan terhadap sistem (Sugara \& Dewantara, 2017).

\section{METODE}

Kegiatan ini dilakukan dalam 3 tahapan yakni survey, implementasi kegiatan dan evaluasi kegiatan. Survey dilakukan di Desa Torongrejo, Kecamatan Tunrejo, Kota Batu. Dalam langkah ini dilakukan analisa tentang potensi implementasi digitalisasi desa di Torongrejo. Tim Kelompok 22 melakukan wawancara terkait potensi desa dan pemanfaatan digital didalam mengembangkan potensi yang ada didesa sehingga dapat dikembangkan dan dapat meningkatkan perekonomian di desa untuk menuju menjadi desa yang sejahtera dan mandiri kedepannya.

\section{HASIL DAN PEMBAHASAN}

Kegiatan Pengabdian kepada masyarakat ini dibagi menjadi dua sesi dengan melakukan sosialisasi pengolahan hasil pertanian yang dikreasi menjadi sesuatu yang memiliki nilai jual dan materi dan diskusi Tanya jawab mengenai pemanfaatan tehnologi 4.0 guna memaksimalkan harga pasar.

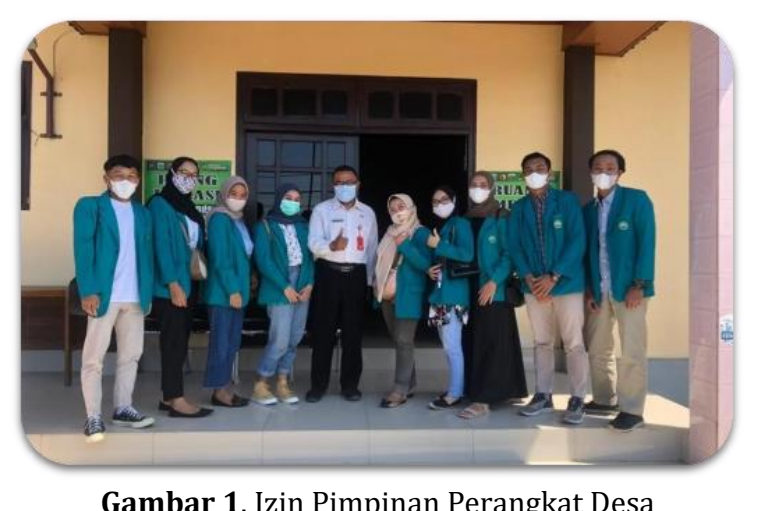

Gambar 1. Izin Pimpinan Perangkat Desa 
Kegiatan pengabdian masyarakat ini diikuti oleh kelompok petani perempuan dan laki-laki dan beberapa perwakilan UMKM serta perangkat desa Torongrejo. Pada kegiatan ini beberapa dosen menyampaikan Materinya kepada Masyarakat Desa, Materi pertama adalah tentang "Branding melalui Digital Marketing" dilanjutkan dengan penyampaian materi kedua mengenai Pemanfaatan Tehnologi Untuk Meningkatkan Penjualan ditengah Pandemi. Karena keterbatasan waktu, pemateri yang melakukan presentasi tidak secara maksimal, sehingga peserta di berikan waktu untuk diskusi Tanya jawab. Berikut nama judul materi beserta pemateri dapat dilihat pada tabel 1 sebagai berikut:

Tabel 1. Daftar pemateri kegiatan

\begin{tabular}{ll}
\hline \multicolumn{1}{c}{ Judul Materi Presentase } & \multicolumn{1}{c}{ Pemateri } \\
\hline Branding Melalui Digital & Dr. M. Ridwan Basalamah, SE, \\
Marketing & MM \\
$\begin{array}{l}\text { Pemanfataan Teknologi Untuk } \\
\text { Meningkatkan Penjualan }\end{array}$ & Yusriel Ardian, S.Kom, M.Kom \\
\hline
\end{tabular}

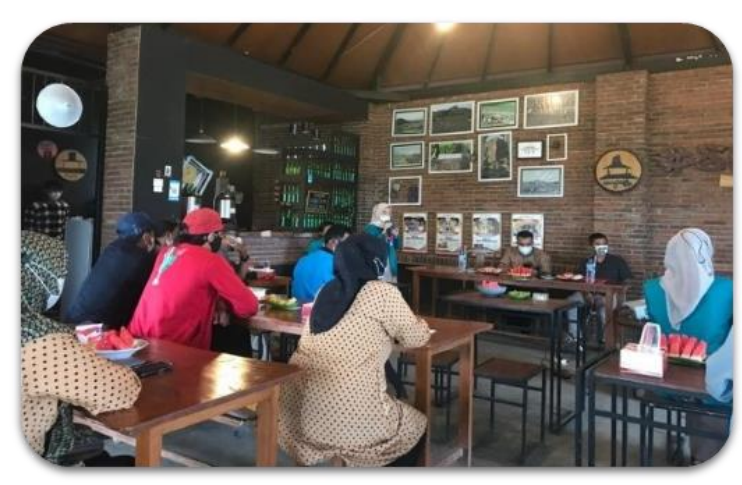

Gambar 2. Pelaksanaan Kegiatan

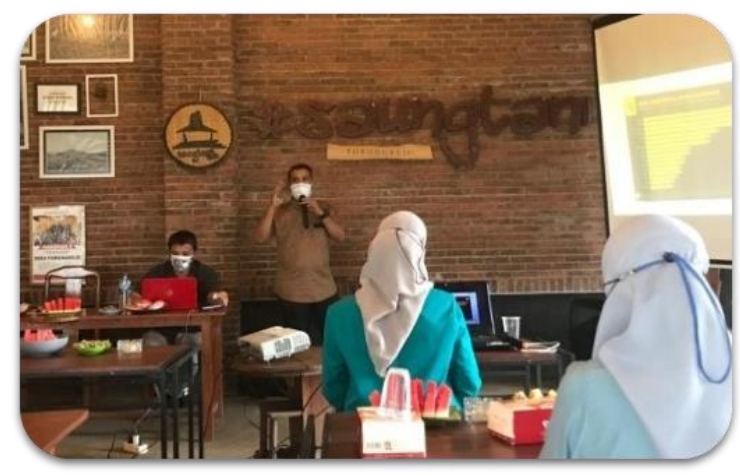

Gambar 3. Penyampaian Materi

Hasil diskusi dari Forum Group Discussion (FGD), kegiatan ini mendapatkan hasil positif dari beberapa pihak seperti kelompok Tani dan UMKM masyarakat Torongrejo dan sangat bermanfaat, apalagi saat kondisi pandemic dan semua dilakukan agar potensi yang di desa setempat dapat menghasilkan produk yang bermanfaat dan meningkatkan penjualan, sehingga masyarakat desa mendapatkan wawasan serta pengetahuan mengenai era digital dan bagaimana branding produk melalui Marketplace. Berikut gambar saat pelaksanaan kegiatan pengabdian kepada masyarakat. 


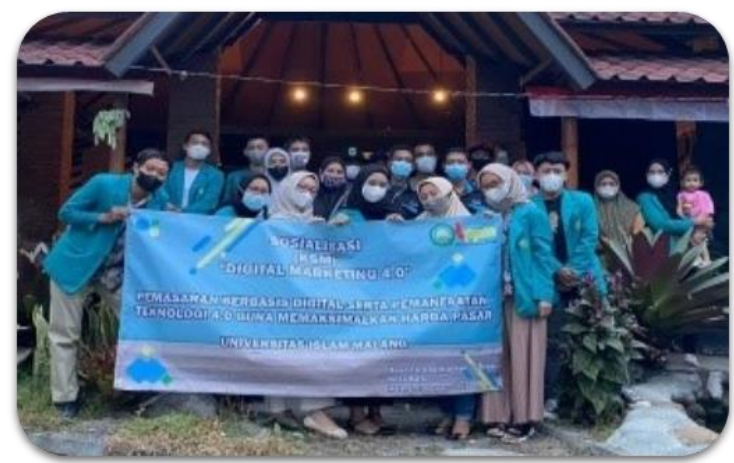

Gambar 4. Penutupan Kegiatan bersama Peserta

Hasil identifikasi menunjukkan bahwa banyak masyarakat di Desa Torongrejo menggunakan teknologi sederhana dalam pemasaran, yaitu didominasi dengan media Whatsapp dan Facebook. Bahkan masih banyak masyarakat dan UMKM yang menjalankan usahanya secara offline tanpa bantuan teknologi. Hasil evaluasi dari kegiatan pelatihan digital marketing menunjukkan bahwa kegiatan ini mendapatkan tanggapan yang positif, dinilai dapat memberikan wawasan dan ilmu, dan memberikan inspirasi. Hampir seluruh pelaku usaha ingin mempraktekan bisnis online ini dalam pengembangan usahanya.

\section{KESIMPULAN}

Desa Torongrejo terletak di lereng Gunung Semeru yang memiliki berbagai potensi dalam bidang ekonomi. KSM Tematik yang dilaksanakan di Desa Torongrejo, Kcamatan Junrejo mendapat respon yang baik dari warga dan segenap perangkat Desa Torongrejo, Masyarakat sangat memerlukan dukungan untuk dapat meningkatkan kesejateraannya, maka kita sebagai mahasiswa harus menjadi motivator dan penggerak inovasi perekonomian bagi masyarakat. Bahwa banyak masyarakat di Desa Torongrejo menggunakan teknologi sederhana dalam pemasaran, yaitu didominasi dengan media Whatsapp dan Facebook. Bahkan masih banyak masyarakat dan UMKM yang menjalankan usahanya secara offline tanpa bantuan teknologi. Hasil evaluasi dari kegiatan pelatihan digital marketing menunjukkan bahwa kegiatan ini mendapatkan tanggapan yang positif, dinilai dapat memberikan wawasan dan ilmu, dan memberikan inspirasi. Hampir seluruh pelaku usaha ingin mempraktekan bisnis online ini dalam pengembangan usahanya.

\section{UCAPAN TERIMA KASIH}

Terima Kasih Untuk Desa Torongrejo terutama bapak Doni Firmansyah selaku Sekretaris Desa dan warga yang telah membantu, mengiringi, dan memberi tempat bernaung untuk pengabdian ksm tematik unisma Torongrejo. Terimakasih untuk temanteman ksm tematik unisma desa Torongrejo sudah berjuang \& bekerja sama dengan sangat baik selama pengabdian ini.

\section{DAFTAR RUJUKAN}

Alwafi, F., \& Magnadi, R. H. (2016). Pengaruh Persepsi Keamanan, Kemudahan Bertransaksi, Kepercayaan Terhadap Toko Dan Pengalaman Berbelanja Terhadap Minat Beli Secara Online Pada Situs Jual Beli Tokopedia.Com. Diponegoro Journal of Management, 5(2), $1-15$.

http://administrasibisnis.studentjournal.ub.ac.id/index.php/jab/article/view/2150

Fidiana, F., Ariestianti, W., Retnani, E. D., \& Widyawati, D. (2021). Strategi ekspansi usaha dan pengelolaan kas berbasis teknologi informasi pada era new normal. Jurnal Inovasi
Hasil
Pengabdian
Masyarakat
(JIPEMAS),
4(2),
251-258. 
https://doi.org/10.33474/jipemas.v4i2.9585

Imaniawan, F. F. D., \& Wati, F. F. (2017). Sistem Informasi Administrasi Kependudukan Berbasis Web Pada Desa Bogangin Sumpiuh. Indonesian Journal on Networking and Security, 7(3), 1-9. https://doi.org/10.2311/ijns.v7i3.1516

Islamic Development Bank (IDB). (2003). Guideline for a National IT Strategy. Islamic Research and Training Institute - IRTI.

Pardani, K. K., \& Damayanthi, I. G. A. E. (2017). Pengaruh Pemanfaatan Teknologi, Partisipasi Pemakai, Manajemen Puncak Dan Kemampuan Pemakai Terhadap Efektivitas Sistem Informasi Akuntansi. E-Jurnal Akuntansi, 19(3), 2234-2261. https://ojs.unud.ac.id/index.php/Akuntansi/article/view/29964

Paryanta, Sutariyani, \& Susilowati, D. (2017). Sistem Informasi Administrasi Kependudukan Berbasis Web Desa Sawahan. IJSE - Indonesian Journal on Software Engineering, 3(2), 77-81. https://doi.org/10.31294/ijse.v3i2.2980

Rizal, M., Mustapita, A. F., \& Kartika Sari, A. F. (2019). Pelatihan Untuk Pengajuan Pembiayaan Mudharabah Perbankan Syariah Sebagai Peningkatan Kinerja UMKM. Jurnal Inovasi Hasil Pengabdian Masyarakat (JIPEMAS), 3(1), 15-22. https://doi.org/10.33474/jipemas.v3i1.2569

Sugara, A., \& Dewantara, R. Y. (2017). Analisis Kepercayaan Dan Kepuasan Terhadap Penggunaan Sistem Transaksi Jual Beli Online (Studi Pada Konsumen "Z"). Jurnal $\begin{array}{llll}\text { Administrasi } \quad \text { Bisnis } & \text { (JAB), } & \text { 8-15. }\end{array}$ http://administrasibisnis.studentjournal.ub.ac.id/index.php/jab/article/view/2150

Wuryantai, A. E. W. (2004). Digitalisasi Masyarakat: Menilik Kekuatan dan Kelemahan Dinamika Era Informasi Digital dan Masyarakat Informasi. Jurnal Ilmu Komunikasi, 1(2), 131-142. https://doi.org/10.24002/jik.v1i2.163 